CLINICAL STUDY

\title{
Polymorphisms in the interleukin-6 receptor gene are associated with bone mineral density and body mass index in Spanish postmenopausal women
}

\author{
M Bustamante ${ }^{1,2,3}$, X Nogués $^{4}$, L Mellibovsky $^{4}$, L Agueda ${ }^{1,2,3}, \mathrm{~S}$ Jurado ${ }^{4}$, E Cáceres ${ }^{4}$, J Blanch ${ }^{4}, \mathrm{R} \mathrm{Carreras}^{4}$, \\ A Díez-Pérez ${ }^{4}$ D Grinberg ${ }^{1,2,3}$ and S Balcells ${ }^{1,2,3}$ \\ ${ }^{1}$ Department of Genetics, University of Barcelona, Barcelona, Spain, ${ }^{2}$ IBUB, Barcelona, Spain, ${ }^{3}$ CIBERER, ISCIII, Barcelona, Spain and ${ }^{4}$ Internal \\ Medicine, URFOA, IMIM, Hospital del Mar, Autonomous University of Barcelona, Barcelona, Spain
}

(Correspondence should be addressed to S Balcells at Departament de Genètica, Facultat de Biologia, Universitat de Barcelona, Avinguda Diagonal, 645, E-08028 Barcelona, Spain; Email: sbalcells@ub.edu)

\begin{abstract}
Objective: Osteoporosis and obesity are complex diseases with a strong genetic component. Bone mineral density (BMD) and body mass index (BMI) linkage studies identified a locus at 1q21-23, where the interleukin-6 receptor (IL6R) gene is located. The IL6R and the gp130 receptors are the mediators of IL6 action. Serum levels of IL6 and sIL6R (the soluble form of IL6R) are higher in several diseases such as osteoporosis or obesity. Variants at IL6R have been associated with BMI and obesity. However, IL6R is an as-yet-unexplored osteoporosis candidate gene.

Design: In the present study we analysed two polymorphisms in the IL6R promoter, $-1435 \mathrm{C} / \mathrm{T}$ (rs3887104) and - $208 \mathrm{G} / \mathrm{A}$ (rs4845617), and the Asp358Ala polymorphism (rs8192284), in relation to both BMD and BMI in a cohort of 559 postmenopausal Spanish women.

Results: The promoter polymorphisms, $-1435 \mathrm{C} / \mathrm{T}$ and $-208 \mathrm{G} / \mathrm{A}$ were associated with femoral neck (FN) BMD $(P=0.011$ and $P=0.025$ respectively). The $\mathrm{C}-\mathrm{A}$ and $\mathrm{T}-\mathrm{G}$ promoter haplotypes were also associated with FN BMD. Additionally, the Asp358Ala variant was associated with lumbar spine BMD $(P=0.038)$. Finally, the $-208 \mathrm{G} / \mathrm{A}$ polymorphism and the $\mathrm{C}-\mathrm{G}$ and $\mathrm{C}-\mathrm{A}$ haplotypes were associated with BMI and obesity, where GG was the risk genotype ( $P=0.033$ for BMI; $P=0.010$ for obesity). Conclusion: These data suggest that variants in the IL6R gene are not only involved in the determination of BMI but also relevant for the determination of BMD. The IL6R gene may belong to the growing list of genes known to be involved in both phenotypes.
\end{abstract}

European Journal of Endocrinology 157 677-684

\section{Introduction}

Osteoporosis and obesity are complex diseases with a strong genetic component. The heritability of bone mineral density (BMD) has been estimated to be between 0.6 and 0.9 depending on body site and sex $(1,2)$, whereas that of body mass index (BMI), a measurement of obesity, has been calculated to be between 0.5 and 0.6 (2). Genome-wide non-parametric linkage analysis is a good method for defining quantitative trait loci (QTLs). One of these loci, identified in relation to lumbar spine (LS) BMD, BMI and type 2 diabetes mellitus (T2DM), is located at 1q21-23 (3-5).

The IL6R gene maps to $1 \mathrm{q} 21.3$ and encodes the interleukin-6 (IL6) receptor- $\alpha$. The action of IL6 is mediated through two kinds of receptors: IL6R (also known as gp80, CD126, IL-6R-1, IL-6R-A or IL-6R- $\alpha$ ) and gp130 (CD130, IL-6R- $\beta$ or oncostatin M receptor). In contrast to gp130, whose expression pattern is wide and whose ligands include several interleukins, IL6R is expressed in a more restricted cell pattern, including the osteoblast and osteoclast progenitors $(6,7)$, and only binds its natural ligand IL6.

The IL6-IL6R complex induces the homodimerization of gp130, which mediates signalling through the JAK-STAT and ras/MAP-kinase pathways (8). IL6R may be found both as a transmembrane and as a soluble molecule (sIL6R). The latter is produced by cleavage of the former, although it may also be generated by alternative splicing $(9-12)$. The binding capacities of IL6R and sIL6R are similar, and the IL6-sIL6R complex acts as an agonist when it binds to gp130, allowing for IL6 signalling in cells that do not express IL6R in their membranes. This process is referred to as transsignalling (8).

IL6 is a pleiotropic cytokine that has multiple effects on different cell types (8). In bone, IL6 is produced by osteoblasts, monocytes and $\mathrm{T}$ cells, and has an antiapoptotic and differentiating effect on osteoblasts (13-15). Also, and more importantly, IL6 induces 
osteoclastogenesis and osteoclast activity $(16,17)$ through RANKL and OPG produced by osteoblasts (6, 18). In human osteoblasts, IL6R cannot transmit IL6 signalling until it is shed into its soluble form (19).

It is generally accepted that serum levels of IL6 and sIL6R increase with age and postmenopausal status and are higher in several pathological processes such as osteoporosis, obesity or diabetes (20-26). IL6 is known to downregulate food intake and energy expenditure through the CNS (27). IL6-deficient mice develop mature-onset obesity (28) and are protected against osteoporosis after ovariectomy (29).

Several polymorphisms have been identified in the IL6R gene, some of which have been associated with obesity, diabetes and periodontitis in different studies (29-34). However, as yet, no polymorphisms of the IL6R gene have been studied in relation to osteoporosis. The aim of the present study is to evaluate two polymorphisms in the IL6R promoter, $-1435 \mathrm{C} / \mathrm{T}$ and $-208 \mathrm{G} / \mathrm{A}$, and the Asp358Ala polymorphism in exon 9 of the gene in relation to LS BMD, femoral neck (FN) BMD, BMI and obesity status. These variants were selected based on their putative functionality. The Asp358Ala is the only non-synonymous SNP in the gene with a known MAF, and the promoter polymorphisms presented putative allele-specific binding capacities for different transcription factors, according to in silico analyses. In a cohort of postmenopausal Spanish women, these polymorphisms and/or their haplotypes were found to have effects on both BMD and BMI.

\section{Materials and methods}

\section{Subjects}

All participants were consecutive, unselected postmenopausal Spanish women attending the baseline visit at the outpatient clinic of the Menopausal Unit of the Hospital del Mar because of menopause. Patients were prospectively recruited and included regardless of their bone density values. Criteria for exclusion from the study were a previous diagnosis of Paget's disease of bone or osteomalacia, metabolic or endocrine disorder or if they were already undergoing treatment such as hormone replacement treatment. Women who had the menopause before the age of 35 were also excluded. The data recorded were age, the number of years since menopause (ysm) for the LS BMD and FN BMD measurements, height and weight. BMI was calculated as weight/height ${ }^{2}$, and obesity was defined as $\mathrm{BMI} \geq 30 \mathrm{~kg} / \mathrm{m}^{2} ; 17.8 \%(n=99)$ of the individuals in the cohort were obese. According to the WHO definition of osteoporosis and based on LS BMD, 30.9\% of the participants were osteoporotic, $42.6 \%$ were osteopenic and $26.5 \%$ were normal. For FN BMD, 19\% of the participants were osteoporotic, $54.1 \%$ were osteopenic and $26.9 \%$ were normal. Regarding osteoporotic fractures, these were present in the cohort in the following percentages: $4.1 \%$ Colles, $7.7 \%$ vertebral, $0.5 \% \mathrm{FN}$ and $4.7 \%$ other types. Given the small numbers, association with fracture was not performed. Blood samples and written informed consent were obtained according to the regulations of the Hospital del Mar Human Research Review Committee for Genetic Procedures. The main characteristics of the participants are listed in Table 1.

\section{BMD analysis}

LS BMD (L2-L4) was measured in all participants $(n=559)$ as part of the standard protocol of the Menopause Unit. FN BMD was also measured in 315 of the women. A dual-energy X-ray densitometer (QDR 4500 SL; Hologic) was used for the measurements. BMD was expressed in grams per square centimetre and in our centre the technique had an in vivo coefficient of variation of $1.0 \%$ for $\mathrm{LS}$ and $1.65 \%$ for $\mathrm{FN}$ measurements.

\section{DNA extraction}

Genomic DNA of the participants was isolated from peripheral leukocytes according to the BloodPrep chemistry protocol (Applied Biosystems). Purification procedures were conducted on an ABI PRISM 6700 Nucleic Acid Workstation (Applied Biosystems).

\section{Genotyping}

Genotyping of $-1435 \mathrm{C} / \mathrm{T}$ and $-208 \mathrm{G} / \mathrm{A} \mathrm{poly}-$ morphisms Typing of $-1435 \mathrm{C} / \mathrm{T}$ (rs3887104) and - 208 G/A (rs4845617) polymorphisms was performed using the SNaPshot method (Applied Biosystems). A PCR fragment was generated in a $25 \mu \mathrm{l}$ reaction containing $20 \mathrm{ng}$ genomic DNA, the indicated buffer, 5\% DMSO, $4 \mathrm{mM} \mathrm{MgCl}_{2}, 0.2 \mathrm{mM}$ of each d-NTP, $0.4 \mu \mathrm{M}$ of each sense primer (5'-GGGGGTCCTTGAGAGAGTTC-3') and antisense primer (5'-CCGGCTCTCTACACACACTG-3') and $1.25 \mathrm{U}$ Taq DNA polymerase

Table 1 Characteristics of the cohort.

\begin{tabular}{lcc}
\hline Variable & $\boldsymbol{N}$ & Mean (s.D.) \\
\hline Weight $(\mathrm{kg})$ & 558 & $64.7(9.8)$ \\
Height $(\mathrm{cm})$ & 556 & $156.2(6.2)$ \\
BMI (kg/m²) & 556 & $26.5(3.9)$ \\
LS_age (years) & 559 & $55.0(8.4)$ \\
LS_ysm (years) & 559 & $7.3(8.2)$ \\
LS_BMD (g/cm $\left.{ }^{2}\right)$ & 559 & $0.847(0.150)$ \\
FN_age (years) & 315 & $58.6(8.7)$ \\
FN_ysm (years) & 315 & $10.5(8.9)$ \\
FN_BMD (g/cm ${ }^{2}$ ) & 316 & $0.670(0.114)$
\end{tabular}

BMD, bone mineral density; BMI, body mass index; FN, femoral neck; LS, lumbar spine; ysm, years since menopause. 
(GeneCraft). The PCR involved an initial denaturation step at $94{ }^{\circ} \mathrm{C}$ for $5 \mathrm{~min}$, followed by 38 cycles of denaturation at $94{ }^{\circ} \mathrm{C}$ for $40 \mathrm{~s}$, annealing at $59{ }^{\circ} \mathrm{C}$ for $30 \mathrm{~s}$ and polymerization at $72{ }^{\circ} \mathrm{C}$ for $40 \mathrm{~s}$, with a final elongation step at $72{ }^{\circ} \mathrm{C}$ for $5 \mathrm{~min}$. The SNaPshot reaction was performed in $10 \mu \mathrm{l}$ volume, using $3 \mu \mathrm{l}$ clean PCR product, $3 \mu \mathrm{l}$ SNaPshot Multiplex Reaction Mix (Applied Biosystems) and $0.2 \mu \mathrm{M}$ of each SNaPshot primer. Primer sequences were: $-1435 \mathrm{C} / \mathrm{T}=5^{\prime}$ TTTTTTTTTTTCCAGGTGCTTGTTTCTTTCTTTTTTT-3' and $-208 \mathrm{G} / \mathrm{A}=5^{\prime}$-TTTTTTTTTTTTTTCGCACTGACACTGAGCCGG-3'. The reaction was run using a cycling protocol of $96{ }^{\circ} \mathrm{C}$ for $10 \mathrm{~s}, 50{ }^{\circ} \mathrm{C}$ for $5 \mathrm{~s}$ and $60{ }^{\circ} \mathrm{C}$ for $30 \mathrm{~s}$ for 25 cycles. Clean SNaPshot products were mixed with HiDi formamide and GeneScan-120 LIZ size standard (Applied Biosystems) were denatured at $95{ }^{\circ} \mathrm{C}$ for $5 \mathrm{~min}$ and then loaded into an ABIPRISM 310 Genetic Analyzer (Applied Biosystems). GeneMapper software (Applied Biosystems) was used to analyse the data.

Genotyping of the Asp358Ala polymorphism A fragment of 286 bp containing the Asp358Ala (A/C) (rs8192284) polymorphic site was amplified by PCR using the following pair of primers: sense (5'-AAGCTTGTCAAATGGCCTGT-3') and anti-sense (5'-GGACCCATCTCACCTCAGAA-3') in a final volume of $25 \mu$ l containing $20 \mathrm{ng}$ genomic DNA, the indicated buffer, $4 \mathrm{mM} \mathrm{MgCl}_{2}, 0.2 \mathrm{mM}$ of each d-NTP, $0.4 \mu \mathrm{M}$ of each primer and 1.25 U Taq DNA polymerase (GeneCraft). The PCR consisted of an initial denaturing step at $94{ }^{\circ} \mathrm{C}$ for $5 \mathrm{~min}$, followed by 35 cycles of denaturing at $94{ }^{\circ} \mathrm{C}$ for $40 \mathrm{~s}$, annealing at $63{ }^{\circ} \mathrm{C}$ for $30 \mathrm{~s}$ and polymerization at $72{ }^{\circ} \mathrm{C}$ for $40 \mathrm{~s}$, with a final elongation step at $72{ }^{\circ} \mathrm{C}$ for $5 \mathrm{~min}$. The PCR product was digested with the restriction enzyme Hinf I (Takara) overnight at $37^{\circ} \mathrm{C}$. The homozygote $\mathrm{CC}$ samples remained uncut, while the AA homozygotes gave two DNA fragments of 101 and $185 \mathrm{bp}$.

\section{Linkage disequilibrium calculations and haplotype reconstruction}

The $D^{\prime}$ and $r^{2}$ linkage disequilibrium parameters were calculated using the Haploview software (35). Haplotype frequencies were obtained using Haploview and Haplo.score and showed no detectable differences (36). The Haplo.score software was also used to assign individual haplotypes and their related probabilities.

\section{Statistical analyses}

The statistical power was calculated using the Quanto v.1.1 software (37). For LS BMD $($ mean $=0.847$ and
S.D. $=0.150$ ), at a significance level of 0.05, MAFs of $0.2-0.4$ and 460 individuals, there would be an $80 \%$ power to detect differences in BMD of $0.04 \mathrm{~g} / \mathrm{cm}^{2}$ $(\mathrm{MAF}=0.2)$ and $0.03 \mathrm{~g} / \mathrm{cm}^{2}(\mathrm{MAF}=0.4)$ under an additive genetic model. For FN BMD (mean $=0.670$ and S.D. $=0.114$ ) and 250 individuals, there would be power to detect differences in BMD of $0.04 \mathrm{~g} / \mathrm{cm}^{2}(\mathrm{MAF}=0.2)$ and $0.03 \mathrm{~g} / \mathrm{cm}^{2}(\mathrm{MAF}=0.4)$ under an additive genetic model. For the categorical variable obesity/non-obesity, the sample size of this study $(n=83 / 385)$, with MAFs of $0.2-0.4$ and an $\mathrm{OR}=2$, would give a statistical power of $80 \%$ for both the dominant and additive models.

All the analyses were performed using the SPSS v.11.5 statistical software (SPSS Inc). ANOVA or covariance (ANCOVA) was used to assess the effect of each polymorphism or haplotype on LS BMD, FN BMD and BMI. The covariables used were those with the greatest clinical relevance (BMI and ysm for BMD; ysm for BMI). General, dominant and recessive models were analysed. The $\chi^{2}$ and Fisher's exact tests were used to assess Hardy-Weinberg equilibrium (HWE) and the obesity phenotype among different genotypes and haplotypes. A value of $P<0.05$ was considered statistically significant.

\section{Results}

\section{Genotypes and haplotypes of IL6R}

The IL6R promoter polymorphisms rs3887104 and rs4845617, located -1435 and -208 nucleotides from the translation start site respectively, were genotyped in the cohort. They are separated by $1227 \mathrm{bp}$ and were found to be in strong linkage disequilibrium $\left(D^{\prime}=1\right.$ and $\left.r^{2}=0.11\right)$. Accordingly, only three of the four possible haplotypes were found in the sample. In contrast, the promoter polymorphisms were not in linkage disequilibrium with the exon 9 polymorphism, Asp358Ala (rs8192284), located $\sim 50 \mathrm{~kb}$ downstream $\left(D^{\prime}=0.50\right.$ and $r^{2}=0.03$ for $-1435 \mathrm{C} / \mathrm{T} ; D^{\prime}=0.17$ and $r^{2}=0.03$ for $\left.-208 \mathrm{G} / \mathrm{A}\right)$. Genotypic and allelic frequencies are shown in Table 2. We estimated the short-range haplotypes, which encompass the polymorphisms in the promoter region. The population frequencies and the number of individuals bearing two, one or no copies of each haplotype are listed in Table 3.

\section{Association between genotypes and LS BMD, FN BMD, BMI and obesity status}

Results of the ANCOVA tests between the genotypes and the adjusted phenotypes are shown in Table 4. The two promoter polymorphisms were associated with adjusted FN BMD. The $-1435 \mathrm{C} / \mathrm{T}$ polymorphism was associated under a dominant model $(P=0.011)$ so that carriers of the $\mathrm{CC}$ genotype had higher FN BMD values 
Table 2 Genotypic and allelic frequencies and Hardy-Weinberg equilibrium (HWE) $P$ values.

\begin{tabular}{|c|c|c|c|c|c|}
\hline Polymorphism & Genotype & $N(\%)$ & Allele & Frequency & HWE $P$ value \\
\hline$-1435 \mathrm{C} / \mathrm{T}$ & $\mathrm{CC}$ & 349 (74.4) & C & 0.86 & \\
\hline \multirow[t]{3}{*}{ (rs3887104) } & CT & 109 (23.2) & $\mathrm{T}$ & 0.14 & \\
\hline & TT & $11(2.3)$ & & & \\
\hline & Total & 469 & & & 0.48 \\
\hline$-208 \mathrm{G} / \mathrm{A}$ & GG & $179(38.6)$ & $\mathrm{G}$ & 0.62 & \\
\hline \multirow[t]{2}{*}{ (rs4845617) } & $\begin{array}{l}\text { GA } \\
\text { AA }\end{array}$ & $\begin{array}{r}214(46.1) \\
71(15.3)\end{array}$ & A & 0.38 & \\
\hline & Total & 464 & & & 0.59 \\
\hline Asp358Ala & AA & $162(33.4)$ & $A(A s p)$ & 0.57 & \\
\hline \multirow[t]{3}{*}{ (rs8192284) } & $A C$ & $232(47.8)$ & C (Ala) & 0.43 & \\
\hline & $\mathrm{CC}$ & 91 (18.8) & & & \\
\hline & Total & 485 & & & 0.62 \\
\hline
\end{tabular}

than the rest of the cohort. The downstream polymorphism, $-208 \mathrm{G} / \mathrm{A}$, was associated with adjusted FN BMD under a recessive model $(P=0.025)$. The AA genotype group had a significantly higher mean FN BMD value than the other two groups. Neither of the two promoter polymorphisms was associated with LS BMD. In contrast, the Asp358Ala polymorphism was found to be associated with LS BMD in a recessive manner $(P=0.038)$. Subjects who were homozygotes for the $\mathrm{C}$ allele (Ala) had higher LS BMD than the remaining individuals.

In terms of body mass parameters, only the -208 G/A polymorphism was found to be associated with both BMI $(P=0.033)$ and obesity $(P=0.010)$, under a dominant model. The obesity OR for individuals bearing the GG genotype when compared with those bearing at least one copy of the A allele was 1.89 (95\% CI: 1.18-3.04).

\section{Association between haplotypes and LS BMD, FN BMD, BMI and obesity status}

We analysed the relationship between the number of copies of each short-range haplotype and LS BMD, FN BMD, BMI or obesity status (Table 5). It was observed that carrying two copies of the C-A haplotype was associated with high FN BMD values $(P=0.041)$ while carrying at least one copy of the T-G haplotype was associated with low FN BMD $(P=0.05)$. Figure 1 summarizes these haplotype results for FN BMD. Individuals with $\mathrm{C}-\mathrm{A} / \mathrm{C}-\mathrm{A}$ haplogenotype show

Table 3 Short-range haplotype frequencies and number of individuals bearing 0,1 or 2 copies of each haplotype.

\begin{tabular}{lcccc}
\hline & & \multicolumn{4}{c}{ Number of copies } \\
\cline { 3 - 5 } $\begin{array}{l}\text { Short-range } \\
\text { haplotypes }\end{array}$ & $\boldsymbol{N}(\%)$ & 0 & 1 & 2 \\
\hline C-G & $402(46.2)$ & $122(28.0)$ & $224(51.5)$ & $89(20.5)$ \\
C-A & $345(39.7)$ & $159(36.6)$ & $207(47.6)$ & $69(15.9)$ \\
T-G & $123(14.1)$ & $323(74.3)$ & $101(23.2)$ & $11(2.5)$ \\
Total & 870 & & & \\
\hline
\end{tabular}

significantly higher FN BMD $(P=0.011)$ than those bearing T-G/other haplogenotype. None of the shortrange haplotypes was associated with LS BMD.

On the other hand, bearing two copies of C-G haplotype was associated with higher BMI values $(P=0.035)$. Either two copies of the $\mathrm{C}-\mathrm{G}$ haplotype or no copies of the $C$-A haplotype were also associated with obesity status $(P=0.021$ and $P=0.039$ respectively). The obesity OR for individuals bearing two copies of the C-G haplotype when compared with those bearing one or no copies was 1.95 (1.12-3.37). An OR of 0.59 (0.36-0.96) was obtained for individuals bearing one or two copies of the C-A haplotype when compared with those bearing no copy.

\section{Discussion}

This study is the first association analysis performed between polymorphisms in the IL6R gene and osteoporosis. We studied two polymorphisms in the promoter of this gene and a non-synonymous polymorphism in exon 9. The two promoter polymorphisms were significantly associated with FN BMD, and the missense change was associated with LS BMD, which suggests that IL6R has a role in bone mass determination.

For the promoter polymorphisms, we were able to identify two different genotypic or haplogenotypic groups that show lower or higher than average FN BMD levels (Fig. 1). The low FN BMD group was defined by the individuals bearing at least one copy of the $-1435 \mathrm{~T}$ allele (the same group that carried at least one copy of the T-G haplotype, given that the T-A haplotype was absent from the cohort). The estimated mean FN BMD value of this group, which represented $\sim 25 \%$ of the sample, was $0.037 \mathrm{~g} / \mathrm{cm}^{2}(0.009-0.066)$ lower than the corresponding value for the rest of the cohort. At the other end of the distribution, a high FN BMD group was defined by individuals who were homozygous for the A allele at -208 (all were homozygous for the C-A haplotype, given that the T-A haplotype was absent). This group included more than $15 \%$ of the sample and exhibited an estimated mean FN 
Table 4 Association between interleukin-6 receptor (IL6R) polymorphisms and lumbar spine (LS) bone mineral density (BMD), femoral neck (FN) BMD, body mass index (BMI) and obesity status.

\begin{tabular}{|c|c|c|c|c|c|}
\hline & \multicolumn{3}{|c|}{$\begin{array}{l}\text { BMD and BMI } \\
(\text { mean }(\text { S.E.M }))^{\mathrm{a}}\end{array}$} & \multicolumn{2}{|c|}{$\begin{array}{l}\text { Obesity status } \\
N \text { (frequency) }\end{array}$} \\
\hline & adj_LS_BMD ${ }^{c}$ & adj_FN_BMD ${ }^{c}$ & ${\operatorname{adj} \_B M I^{d}}^{d}$ & Non obese & Obese \\
\hline \multicolumn{6}{|l|}{$-1455 \mathrm{C} / \mathrm{T}$} \\
\hline$N$ & 468 & 262 & 468 & 385 & 83 \\
\hline $\mathrm{CC}$ & $0.847(0.007)$ & $0.680(0.007)$ & $26.5(0.2)$ & 287 (82.2\%) & $62(17.8 \%)$ \\
\hline CT & $0.840(0.007)$ & $0.642(0.013)$ & $26.3(0.4)$ & 89 (81.7\%) & 20 (18.3\%) \\
\hline $\mathrm{TT}$ & $0.808(0.043)$ & $0.655(0.100)$ & $25.9(1.2)$ & $9(90.0 \%)$ & $1(10.0 \%)$ \\
\hline$P$ value ${ }^{\mathrm{e}}$ & 0.627 & 0.040 & 0.675 & 0.803 & \\
\hline$P$ value ${ }^{f}$ & & 0.011 (D) & & & \\
\hline \multicolumn{6}{|l|}{$-208 \mathrm{G} / \mathrm{A}$} \\
\hline$N$ & 462 & 251 & 462 & 376 & 86 \\
\hline$G G$ & $0.847(0.010)$ & $0.668(0.011)$ & $27.0(0.3)$ & $134(75.3 \%)$ & $44(24.7 \%)$ \\
\hline $\mathrm{GA}$ & $0.852(0.009)$ & 0.669 (0.009) & $26.1(0.3)$ & $183(85.9 \%)$ & 30 (14.1\%) \\
\hline AA & $0.847(0.016)$ & $0.707(0.015)$ & $26.8(0.4)$ & $59(83.1 \%)$ & $12(16.9 \%)$ \\
\hline$P$ value $^{\mathrm{e}}$ & 0.917 & 0.081 & 0.038 & 0.025 & \\
\hline$P$ value $^{f}$ & & $0.025(\mathrm{R})$ & $0.033(\mathrm{D})$ & $0.010(\mathrm{D})^{\mathrm{g}}$ & \\
\hline \multicolumn{6}{|l|}{ Asp358Ala } \\
\hline$N$ & 484 & 256 & 484 & 402 & 82 \\
\hline AA (AspAsp) & $0.847(0.011)$ & $0.664(0.011)$ & $26.6(0.3)$ & $130(80.2 \%)$ & 32 (19.8\%) \\
\hline CA (AspAla) & $0.850(0.009)$ & 0.675 (0.009) & $26.3(0.3)$ & $196(84.5 \%)$ & 36 (15.5\%) \\
\hline CC (AlaAla) & $0.882(0.014)$ & $0.693(0.015)$ & $26.2(0.4)$ & $76(84.4 \%)$ & $14(15.6 \%)$ \\
\hline$P$ value & 0.115 & 0.276 & 0.695 & 0.505 & \\
\hline$P$ value $^{f}$ & $0.038(R)$ & & & & \\
\hline
\end{tabular}

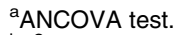

${ }^{b} \chi^{2}$ test.

${ }^{\mathrm{c} A d j u s t e d}$ by $\mathrm{BMI}$ and years since menopause.

${ }^{d}$ Adjusted by years since menopause.

${ }^{\text {e }}$ General $P$ value.

${ }^{\dagger}$ Alternative $P$ value. D, Dominant model; $R$, recessive model.

'Fisher's exact.

BMD that was $0.038 \mathrm{~g} / \mathrm{cm}^{2}(0.005-0.071)$ higher than the corresponding value for the rest of the cohort. Therefore, it seems that both polymorphisms are important in defining FN BMD.

Although there is no evidence of the functionality of the $-1435 \mathrm{C} / \mathrm{T}$ and $-208 \mathrm{G} / \mathrm{A}$ polymorphisms, these promoter SNPs showed allele-specific consensus sequences for factors such as $\mathrm{Cdx} 2$ or NF-1, according to analyses performed with the Genomatix and Signal Scan software packages $(38,39)$. It is also possible that these polymorphisms could be tagging other functional ones. According to HapMap data, the polymorphisms lie in a haplotypic block of more than $20 \mathrm{~kb}$ at the $5^{\prime}$ flank of the IL6R gene, which includes 'synonymous' polymorphisms (according to an $r^{2} \geq 0.8$ ) for the -208 G/A SNP. No data for the $-1435 \mathrm{C} / \mathrm{T}$ polymorphism are available in HapMap.

In contrast to the promoter SNPs, the Asp358Ala polymorphism was found to be associated with LS BMD and not with FN BMD. This difference may be explained by the fact that LS and FN have different proportions of trabecular and cortical bone and are partially determined by different genetic variants (2).

Homozygotes for the Ala allele showed higher LS BMD values. The Asp358 is located in the site that is more frequently cleaved to produce the soluble sIL6R (40). Functional analyses have shown that point mutations changing it to Gly, Phe, Leu or Arg reduce the shedding to $22-54 \%$ of the wild-type sIL6R and the double point mutation Gln357-Asp358 to Ala357Ala 358 reduces the shedding to $34 \%$. Consequently, the Ala358 allele could be related to lower shedding and therefore to lower sIL6R levels. This, in turn, could lead to reduced osteoclastogenesis, which would be consistent with the higher BMD observed. However, we cannot rule out the possibility that this SNP is in high linkage disequilibrium with other functional polymorphisms. The Asp358Ala polymorphism lies in an LD block of $32 \mathrm{~kb}$, which contains seven confirmed synonymous intronic polymorphisms.

We also investigated the relationship of the IL6R polymorphisms with obesity and found the $-208 \mathrm{G} / \mathrm{A}$ SNP to be associated with both BMI and obesity status in the cohort. In particular, the GG genotype conferred an increased risk of obesity $(\mathrm{OR}=1.89(1.18-3.04))$ and a similar effect was observed when looking at haplotypes: individuals who were homozygous for the C-G haplotype or those carrying no copies of the C-A haplotype (which are all homozygotes -208 GG, given the strong linkage disequilibrium observed) had higher BMI. Previous studies have associated polymorphisms of the IL6R gene with BMI. In particular, the Asp358 allele was related to higher BMI in a group of Pima Indians (30) and in a Spanish population (33). In contrast, 
Table 5 Association between interleukin-6 receptor (IL6R) short-range haplotypes and lumbar spine (LS) bone mineral density (BMD), femoral neck (FN) BMD, body mass index (BMI) and obesity status.

\begin{tabular}{|c|c|c|c|c|c|}
\hline & \multicolumn{3}{|c|}{$\begin{array}{l}\text { BMD and BMI Variables } \\
(\text { mean (S.E.M. }))^{\mathrm{a}}\end{array}$} & \multicolumn{2}{|c|}{$\begin{array}{l}\text { Obesity status } \\
N \text { (frequency) }\end{array}$} \\
\hline & adj_LS_BMD ${ }^{c}$ & adj_FN_BMD ${ }^{c}$ & $\operatorname{adj} \_B M I^{d}$ & Non obese & Obese \\
\hline \multicolumn{6}{|l|}{ CG Haplotype } \\
\hline$N$ & 434 & 234 & 434 & 355 & 79 \\
\hline 0 copies of C-G & $0.843(0.012)$ & $0.686(0.012)$ & $26.4(0.3)$ & $100(82.6 \%)$ & 21 (17.4\%) \\
\hline 1 copy of $C-G$ & $0.854(0.009)$ & $0.666(0.009)$ & $26.2(0.2)$ & $190(84.8 \%)$ & 34 (15.2\%) \\
\hline 2 copies of $C-G$ & $0.850(0.014)$ & $0.682(0.015)$ & $27.2(0.4)$ & $65(73.0 \%)$ & $24(27.0 \%)$ \\
\hline$P$ value & 0.790 & 0.398 & 0.099 & 0.049 & \\
\hline$P$ value $^{f}$ & & & $0.035(R)$ & $0.021(\mathrm{R})$ & \\
\hline \multicolumn{6}{|l|}{ CA Haplotype } \\
\hline$N$ & 434 & 234 & 434 & 355 & 79 \\
\hline 0 copies of C-A & $0.848(0.011)$ & $0.668(0.012)$ & $26.9(0.3)$ & $121(76.6 \%)$ & 3 (23.4\%) \\
\hline 1 copy of C-A & $0.854(0.009)$ & $0.669(0.009)$ & $26.1(0.3)$ & $177(85.5 \%)$ & $30(14.5 \%)$ \\
\hline 2 copies of $C-A$ & $0.843(0.016)$ & $0.704(0.016)$ & $26.7(0.4)$ & $57(82.6 \%)$ & $12(17.4 \%)$ \\
\hline$P$ value & 0.810 & 0.124 & 0.112 & 0.089 & \\
\hline$P$ value $^{f}$ & & $0.041(\mathrm{R})$ & & $0.039(D)^{g}$ & \\
\hline \multicolumn{6}{|l|}{ TG Haplotype } \\
\hline$N$ & 434 & 234 & 434 & 355 & 79 \\
\hline 0 copies of $T-G$ & $0.851(0.008)$ & $0.682(0.007)$ & $26.6(0.2)$ & 265 (82.0\%) & 58 (18.0\%) \\
\hline 1 copy of $T-G$ & $0.851(0.014)$ & $0.651(0.014)$ & $26.3(0.4)$ & $81(80.2 \%)$ & 20 (19.8\%) \\
\hline 2 copies of T-G & $0.810(0.043)$ & $0.655(0.100)$ & $25.9(1.2)$ & $9(90.0 \%)$ & $1(10.0 \%)$ \\
\hline$P$ value & 0.646 & 0.148 & 0.744 & 0.727 & \\
\hline$P$ value $^{f}$ & & 0.050 (D) & & & \\
\hline
\end{tabular}

aANCOVA test.

${ }^{\mathrm{b}} \chi^{2}$ test.

${ }^{\mathrm{c}}$ Adjusted by BMI and years since menopause.

${ }^{\mathrm{d}}$ Adjusted by years since menopause.

${ }^{e}$ General $P$ value.

${ }^{\dagger}$ Alternative $P$ value. D, dominant model; $\mathrm{R}$, recessive model.

${ }^{\text {g}}$ Fisher's exact.

Hamid et al. (31), Wang et al. (32) and the present study failed to detect this association in a Danish, an American and another Spanish population respectively. Differences in study design and in the age, sex and ethnicity of the patients make it difficult to draw comparisons between these studies. A comprehensive analysis of the complete IL6R genomic region in a highpowered study might help to clarify the role of IL6R variants in obesity. Additionally, functional analyses of particular SNPs might help to understand the molecular basis of the positive association results.

In this study the $-208 \mathrm{G} / \mathrm{A}$ polymorphism at the IL6R gene was found to be associated with FN BMD and BMI simultaneously. While women who were homozygous for the major allele (G) were at higher risk of obesity, those who were homozygous for the minor allele (A) had higher average FN BMD. This is not the first time that polymorphisms in a gene are related simultaneously to osteoporosis and obesity. For example, genes such as IL6 and RANK, both participating in bone resorption, were associated with BMD and with BMI (41-43). Although it is generally considered that obese women are at lower risk of osteoporosis, there are some controversial results that question this assumption (44). It has recently been proposed that while lean mass is positively correlated with BMD, fat mass is inversely correlated with it (45). A positive correlation between BMI and FN BMD was observed in our cohort but it disappeared when the sample was stratified according to the $-208 \mathrm{G} / \mathrm{A}$ genotype. Obesity and osteoporosis are diseases that share several

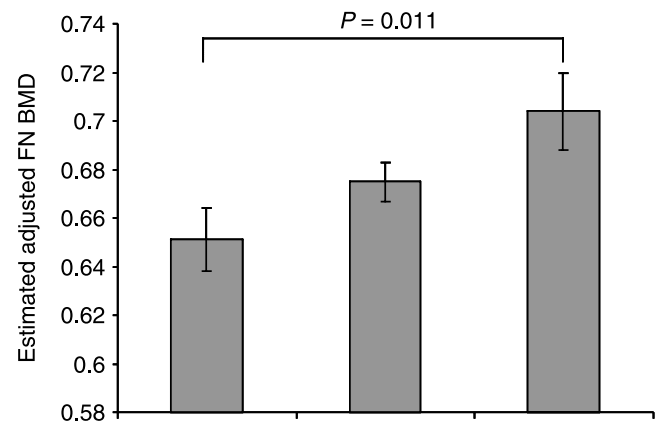

\begin{tabular}{|l|l|l|l|}
\hline Haplogenotype & T-G/_ & $\begin{array}{l}\text { C-G/C-G or } \\
\text { C-G/C-A }\end{array}$ & C-A/C-A \\
\hline$-1435 \mathrm{C} / \mathrm{T}$ & $\mathrm{T}_{-}$ & CC & CC \\
\hline$-208 \mathrm{G} / \mathrm{A}$ & $\mathrm{G}_{-}$ & $\mathrm{G}_{-}$ & AA \\
\hline $\mathrm{N}(\%)$ & $54(23 \%)$ & $140(60 \%)$ & $40(17 \%)$ \\
\hline
\end{tabular}

Figure 1 Mean adjusted FN BMD and standard error for three haplogenotype categories. Individuals bearing C-A/C-A (17\%) had higher FN BMD and individuals carrying at least one copy of the T-G haplotype $(23 \%)$ had lower FN BMD than the rest of the cohort. Comparison of the two extreme groups showed a significant difference (ANCOVA, $P=0.011$ ). 
features, including a genetic basis. They both can be traced to dysregulation of a common precursor cell. Both diseases are under CNS control and regulated by multiple shared signal molecules such as oestrogens, leptin or IL6 (44). In particular, Deng et al. (2) observed that BMI and BMD shared 10-20\% genetic variation and suggested that this could be caused by shared genes with pleiotropic effects on both BMI and BMD. It was also observed that the magnitude of shared genetic and environmental components was higher between FN BMD and BMI than between LS BMD and BMI. This is in agreement with the results of this study in which the $-208 \mathrm{G} / \mathrm{A}$ polymorphism of IL6R is related to BMI and FN BMD, but not to LS BMD.

In summary, we reported a significant association between polymorphisms of the IL6R gene and BMD, a surrogate marker for osteoporosis. We also observed an association with obesity. Although our sample size is intermediate and the statistical power is therefore limited, the results of this study suggest that IL6R influences these two phenotypes. It is necessary to replicate these results in other populations and it would be very interesting to perform complementary functional analyses.

\section{Acknowledgements}

Robin Rycroft provided editorial assistance. M B received a fellowship from the Spanish Ministry of Science and Technology. This study was supported by grants from: the Spanish Ministry of Science and Technology (PM1999-0131-C02-01); the Spanish Ministry of Education and Science (SAF2004-06085); the European Commission (GENOMOS Project; grant QLRT-200102629); the Spanish Ministry of Health (FIS 98/1952 and PM 99-0131-C02-01); and the Catalan Department of Universities, Research and the Information Society (2005SGR 00762 and 2005SGR 00848).

\section{References}

1 Deng HW, Chen WM, Conway T, Zhou Y, Davies KM, Stegman MR, Deng H \& Recker RR. Determination of bone mineral density of the hip and spine in human pedigrees by genetic and life-style factors. Genetic Epidemiology 200019 160-177.

2 Deng FY, Lei SF, Li MX, Jiang C, Dvornyk V \& Deng HW. Genetic determination and correlation of body mass index and bone mineral density at the spine and hip in Chinese Han ethnicity. Osteoporosis International $2006 \mathbf{1 7} 119-124$.

3 Huang QY \& Kung AW. Genetics of osteoporosis. Molecular Genetics and Metabolism 200688 295-306.

4 Snyder EE, Walts B, Perusse L, Chagnon YC, Weisnagel SJ, Rankinen T \& Bouchard C. The human obesity gene map: the 2003 update. Obesity Research 200412 369-439.

5 Barroso I. Genetics of type 2 diabetes. Diabetic Medicine 200522 $517-535$.

6 Udagawa N, Takahashi N, Katagiri T, Tamura T, Wada S, Findlay DM, Martin TJ, Hirota H, Taga T, Kishimoto T \& Suda T. Interleukin (IL)-6 induction of osteoclast differentiation depends on IL-6 receptors expressed on osteoblastic cells but not on osteoclast progenitors. Journal of Experimental Medicine 1995182 $1461-1468$

7 Franchimont N, Lambert C, Huynen P, Ribbens C, Relic B, Chariot A, Bours V, Piette J, Merville MP \& Malaise M. Interleukin-6 receptor shedding is enhanced by interleukin1 beta and tumor necrosis factor alpha and is partially mediated by tumor necrosis factor alpha-converting enzyme in osteoblastlike cells. Arthritis and Rheumatism 200552 84-93.

8 Kallen KJ. The role of transsignalling via the agonistic soluble IL-6 receptor in human diseases. Biochimica et Biophysic Acta 2002 $1592323-343$.

9 Lust JA, Donovan KA, Kline MP, Greipp PR, Kyle RA \& Maihle NJ. Isolation of an mRNA encoding a soluble form of the human interleukin-6 receptor. Cytokine 19924 96-100.

10 Mullberg J. Dittrich E, Graeve L, Gerhartz C, Yasukawa K, Taga T, Kishimoto T, Heinrich PC \& Rose-John S. Differential shedding of the two subunits of the interleukin-6 receptor. FEBS Letters 1993 332 174-178.

11 Muller-Newen G, Kohne C, Keul R, Hemmann U, Muller-Esterl W, Wijdenes J, Brakenhoff JP, Hart MH \& Heinrich PC. Purification and characterization of the soluble interleukin- 6 receptor from human plasma and identification of an isoform generated through alternative splicing. European Journal of Biochemistry 1996236 $837-842$.

12 Althoff K, Reddy P, Voltz N, Rose-John S \& Mullberg J. Shedding of interleukin- 6 receptor and tumor necrosis factor alpha. Contribution of the stalk sequence to the cleavage pattern of transmembrane proteins. European Journal of Biochemistry 2000 267 2624-2631.

13 Bellido T, O'Brien CA, Roberson PK \& Manolagas SC. Transcriptional activation of the (WAF1,CIP1,SDI) gene by interleukin-6 type cytokines. A prerequisite for their pro-differentiating and anti-apoptotic effects on human osteoblastic cells. Journal of Biological Chemistry 1998273 21137-21144.

14 Jilka RL, Weinstein RS, Bellido T, Parfitt AM \& Manolagas SC. Osteoblast programmed cell death (apoptosis): modulation by growth factors and cytokines. Journal of Bone and Mineral Research 199813 793-802.

15 Erices A, Conget P, Rojas C \& Minguell JJ. Gp130 activation by soluble interleukin- 6 receptor/interleukin- 6 enhances osteoblastic differentiation of human bone marrow-derived mesenchymal stem cells. Experimental Cell Research 2002280 24-32.

16 Jilka RL, Hangoc G, Girasole G, Passeri G, Williams DC, Abrams JS, Boyce B, Broxmeyer H \& Manolagas SC. Increased osteoclast development after estrogen loss: mediation by interleukin- 6 . Science $199225788-91$.

17 Tamura T, Udagawa N, Takahashi N, Miyaura C, Tanaka S, Yamada Y, Koishihara Y, Ohsugi Y, Kumaki K Taga T et al. Soluble interleukin-6 receptor triggers osteoclast formation by interleukin 6. PNAS 199390 11924-11928.

18 Palmqvist P, Persson E, Conaway HH \& Lerner UH. IL-6, leukemia inhibitory factor, and oncostatin $\mathrm{M}$ stimulate bone resorption and regulate the expression of receptor activator of NF- $\kappa \mathrm{B}$ ligand, osteoprotegerin, and receptor activator of NF- $\kappa \mathrm{B}$ in mouse calvariae. Journal of Immunology $20021693353-3362$.

19 Vermes C, Jacobs JJ, Zhang J, Firneisz G, Roebuck KA \& Glant TT. Shedding of the interleukin-6 (IL-6) receptor (gp80) determines the ability of IL-6 to induce gp130 phosphorylation in human osteoblasts. Journal of Biological Chemistry 2002277 16879-16887.

20 Abrahamsen B, Bonnevie-Nielsen V, Ebbesen EN, Gram J \& BeckNielsen H. Cytokines and bone loss in a 5-year longitudinal study hormone replacement therapy suppresses serum soluble interleukin-6 receptor and increases interleukin-1-receptor antagonist: the Danish Osteoporosis Prevention Study. Journal of Bone and Mineral Research 200015 1545-1554.

21 Giuliani N, Sansoni P, Girasole G, Vescovini R, Passeri G, Passeri M \& Pedrazzoni M. Serum interleukin-6, soluble interleukin-6 receptor and soluble gp130 exhibit different patterns of age- and menopause-related changes. Experimental Gerontology 200136 $547-557$. 
22 Scheidt-Nave C, Bismar H, Leidig-Bruckner G, Woitge H, Seibel MJ, Ziegler R \& Pfeilschifter J. Serum interleukin 6 is a major predictor of bone loss in women specific to the first decade past menopause. Journal of Clinical Endocrinology and Metabolism $2001 \mathbf{8 6}$ 2032-2042.

23 Mohamed-Ali V, Goodrick S, Rawesh A, Katz DR, Miles JM, Yudkin JS, Klein S \& Coppack SW. Subcutaneous adipose tissue releases interleukin-6, but not tumor necrosis factor-alpha, in vivo. Journal of Clinical Endocrinology and Metabolism $1997 \mathbf{8 2}$ 4196-4200.

24 Fried SK, Bunkin DA \& Greenberg AS. Omental and subcutaneous adipose tissues of obese subjects release interleukin-6: depot difference and regulation by glucocorticoid. Journal of Clinical Endocrinology and Metabolism $1998 \mathbf{8 3} 847-850$.

25 Kado S, Nagase T \& Nagata N. Circulating levels of interleukin-6, its soluble receptor and interleukin-6/interleukin-6 receptor complexes in patients with type 2 diabetes mellitus. Acta Diabetologia 199936 67-72.

26 Vgontzas AN, Bixler EO, Papanicolaou DA \& Chrousos GP. Chronic systemic inflammation in overweight and obese adults. Journal of the American Medical Association 20002832235 (author reply 2236).

27 Jansson JO, Wallenius K, Wernstedt I, Ohlsson C, Dickson SL \& Wallenius V. On the site and mechanism of action of the antiobesity effects of interleukin-6. Growth Hormone and IGF Research 200313 (Suppl A) S28-S32.

28 Escobar-Morreale HF, Calvo RM, Villuendas G, Sancho J \& San Millan JL. Association of polymorphisms in the interleukin 6 receptor complex with obesity and hyperandrogenism. Obesity Research 200311 987-996.

29 Poli V, Balena R, Fattori E, Markatos A, Yamamoto M, Tanaka H, Ciliberto G, Rodan GA \& Costantini F. Interleukin-6 deficient mice are protected from bone loss caused by estrogen depletion. EMBO Journal 199413 1189-1196.

30 Wolford JK, Colligan PB, Gruber JD \& Bogardus C. Variants in the interleukin 6 receptor gene are associated with obesity in Pima Indians. Molecular Genetics and Metabolism 200380 338-343.

31 Hamid YH, Urhammer SA, Jensen DP, Glumer C, Borch-Johnsen K, Jorgensen T, Hansen T \& Pedersen O. Variation in the interleukin-6 receptor gene associates with type 2 diabetes in Danish whites. Diabetes 200453 3342-3345.

32 Wang H, Zhang Z, Chu W, Hale T, Cooper JJ \& Elbein SC. Molecular screening and association analyses of the interleukin 6 receptor gene variants with type 2 diabetes, diabetic nephropathy, and insulin sensitivity. Journal of Clinical Endocrinology and Metabolism $2005901123-1129$.

33 Esteve E, Villuendas G, Mallolas J, Vendrell J, Lopez-Bermejo A, Rodriguez M, Recasens M, Ricart W, San Millan JL, EscobarMorreale H, Richart C \& Fernandez-Real JM. Polymorphisms in the interleukin- 6 receptor gene are associated with body mass index and with characteristics of the metabolic syndrome. Clinical Endocrinology $2006 \mathbf{6 5} 88-91$.
34 Galicia JC, Tai H, Komatsu Y, Shimada Y, Ikezawa I \& Yoshie H. Interleukin-6 receptor gene polymorphisms and periodontitis in a non-smoking Japanese population. Journal of Clinical Periodontology 200633 704-709.

35 Barrett JC, Fry B, Maller J \& Daly MJ. Haploview: analysis and visualization of LD and haplotype maps. Bioinformatics $2005 \mathbf{2 1}$ 263-265.

36 Schaid DJ, Rowland CM, Tines DE, Jacobson RM \& Poland GA. Score tests for association between traits and haplotypes when linkage phase is ambiguous. American Journal of Human Genetics $200270425-434$.

37 Gauderman W \& Morrison J. QUANTO 1.1: A computer program for power and sample size calculations for genetic-epidemiology studies.

38 Cartharius K, Frech K, Grote K, Klocke B, Haltmeier M, Klingenhoff A, Frisch M, Bayerlein M \& Werner T. MatInspector and beyond: promoter analysis based on transcription factor binding sites. Bioinformatics 200521 2933-2942.

39 Prestridge DS. SIGNAL SCAN:, a computer program that scans DNA sequences for eukaryotic transcriptional elements. Computer Applications in the Biosciences 19917 203-206.

40 Mullberg J, Oberthur W, Lottspeich F, Mehl E, Dittrich E, Graeve L, Heinrich PC \& Rose-John S. The soluble human IL-6 receptor. Mutational characterization of the proteolytic cleavage site. Journal of Immunology 1994152 4958-4968.

41 Huang QY, Shen H, Deng HY, Conway T, Davies KM, Li JL, Recker RR \& Deng HW. Linkage and association of the CA repeat polymorphism of the IL6 gene, obesity-related phenotypes, and bone mineral density (BMD) in two independent Caucasian populations. Journal of Human Genetics $2003 \mathbf{4 8} 430-437$.

42 Xiong DH, Shen H, Zhao LJ, Xiao P, Yang TL, Guo Y, Wang W, Guo YF, Liu YJ, Recker RR \& Deng HW. Robust and comprehensive analysis of 20 osteoporosis candidate genes by very high-density single-nucleotide polymorphism screen among 405 white nuclear families identified significant association and gene-gene interaction. Journal of Bone and Mineral Research 200621 1678-1695.

43 Zhao LJ, Guo YF, Xiong DH, Xiao P, Recker RR \& Deng HW. Is a gene important for bone resorption a candidate for obesity? An association and linkage study on the RANK (receptor activator of nuclear factor- $\kappa \mathrm{B})$ gene in a large Caucasian sample Human Genetics 2006120 561-570.

44 Rosen CJ \& Bouxsein ML. Mechanisms of disease: is osteoporosis the obesity of bone? Nature Clinical Practice. Rheumatology 20062 35-43.

45 Zhao LJ, Liu YJ, Liu PY, Hamilton J, Recker RR \& Deng HW. Relationship of obesity with osteoporosis. Journal of Clinical Endocrinology and Metabolism 200792 1640-1646.

Received 20 July 2007

Accepted 29 August 2007 